Original research article

\title{
Professional well-being of nurses in Southwest Hungarian hospitals
}

\author{
Szabolcs Cseh ${ }^{1 *}$, Boglárka Zorga ${ }^{1}$, Dávid Sipos ${ }^{1,2,3}$, Judit Fináncz ${ }^{4}$, Melinda Csima 4 \\ ${ }^{1}$ University of Pécs, Faculty of Health Sciences, Doctoral School, Pécs, Hungary \\ ${ }^{2}$ University of Pécs, Faculty of Health Sciences, Department of Medical Imaging, Pécs, Hungary \\ ${ }^{3}$ Somogy County Mór Kaposi Teaching Hospital Dr. József Baka Diagnostic, Radiation Oncology, Research and Teaching Center, Kaposvár, Hungary \\ ${ }^{4}$ Szent István University Kaposvár Campus, Faculty of Pedagogy, Kaposvár, Hungary
}

\begin{abstract}
Objective: The purpose of the research was to explore nurses' professional well-being at work and its differentiating factors.

Methods: The tool of the cross-sectional, quantitative, descriptive research was a questionnaire, which included questions referring to sociodemographic characteristics, along with validated questionnaires widely used in the international research literature (Maslach Burnout Inventory (hereafter MBI), Beck Depression, Diener Quality of Life) and questions focusing on the exploration of the workplace climate. Following a simple, non-random sampling procedure, the responses of 581 professionals working in nursing job positions were included in the analysis.

Results: Examining burnout, it has been found that the nurses involved in the survey show a more unfavourable picture in the dimensions of depersonalization and emotional exhaustion, compared to MBI normal values. On the other hand, the average value of personal accomplishment proved to be higher among them, which means that the respondents feel their efforts to be more successful and more positive at work. The organizational characteristics of the workplace $(F=2.875 ; p=0.009)$, along with the social appreciation of the job position $(F=4.275 ; p<0.001)$ significantly influence overall satisfaction with life.

Conclusions: The promotion of well-being at work is of utmost importance among health professionals (who are increasingly exposed to stress and burnout), especially among nurses directly participating in inpatient care.
\end{abstract}

Keywords: Burnout; Nurses; Professional well-being; Workplace climate

\section{Introduction}

Healthcare professionals' well-being at work is a widely studied and well-known phenomenon. The COVID-19 epidemic, which grew into a pandemic in 2020, drew people's attention to the circumstances of those working in this field - and it was not only researchers in the healthcare professions who took notice, but lay people too. All over the world, we witnessed people expressing their solidarity with those working on the front line in different ways. However, it is not only the epidemiological situation which makes it necessary to study the living and working conditions of healthcare workers, but also the known fact that those who guard over the health of the population do their very best day by day to restore the health of those in need of medical care, putting aside their own individual problems. In the long term this activity is a demanding task - both physically and mentally. Research literature now regards it as a fact that 'professions dealing with people' carry the risk that the person practising his/her profession will become overwhelmed by the problems they constantly face, and somatic, behavioural, emotional and mental symptoms will appear in their lives (Fekete, 1991). Physical and mental exhaustion over the decades spent in health care can result in burnout. This outcome should be interpreted as a response by the individual to chronic emotional and interpersonal stress processes (Maslach and Jackson 1981). The phenomenon may have several negative effects on the individual, on the work processes and, last but not least, on patient care itself. Eventually, burnout can even result in leaving the medical profession (Sipos et al., 2017). However, burnout, due to the increased mental and physical strain, is only one of the several factors that fundamentally determine the well-being of healthcare professionals at work.

The scientific foundation of the term 'well-being' was closely related to studies on quality of life (Diener et al., 1999; Kopp and Kovács, 2006; Szántó et al., 2016; Veenhoven, 2007), which mainly focused on objective indicators initially (Szabó, 2003). In connection with Diener's work (1995), the view became widespread that the objective measurement of material goods in itself is not sufficient to describe the well-being of a society, so researchers have also made subjective indicators

\footnotetext{
* Corresponding author: Szabolcs Cseh, University of Pécs, Faculty of Health Sciences, Doctoral School, Pécs, Hungary; e-mail: cseh.szabolcs@live.com http://doi.org/10.32725/kont.2021.016

Submitted: 2021-02-08 • Accepted: 2021-04-06 • Prepublished online: 2021-04-14 
the subject of their study (Hegedús, 2001). One of the most frequently studied components of wellbeing (in other words positive mental health or quality of life) is life satisfaction, which - according to one of the most widespread views - is the cognitive assessment of the person's overall quality of life, based on the person's own criteria (Diener et al., 1985). This formulation emphasises the cognitive nature of the assessment, thus separating it from other possible components of well-being (primarily from emotional experiences) and also highlights the element of subjective assessment. The evaluation criteria are determined by the interviewee himself/ herself and not by the researcher. In his study, Warr (1994) distinguishes two levels of measuring well-being: the first level focuses on measuring overall well-being, regardless of context. The second level uses a context-specific way to examine well-being that the individual experiences in their family or work environment. The relevant literature places the phenomenon in a different interpretive framework when capturing well-being at work. Accordingly, to describe occupation-specific well-being, we can come across several terms, including but not limited to: job-related well-being (Warr, 1994), work-related well-being (see Van Horn et al., 2004), occupational well-being (see Van Horn et al., 2004) professionals' satisfaction (see Briones et al., 2010), professional well-being (see Aelterman et al., 2007; Yildirim, 2014). Based on the above, it can be seen that although there is no official definition of well-being at work, it can be captured through various indicators. Job satisfaction, working conditions, quality of work and occupational health can be appropriate indicators of well-being at work. In general, we can say that the concept of well-being at work includes physical and mental well-being, psychosocial factors and the work environment.

Internationally, Tomo and Simone (2017) drew attention to the fact that before 2013, although several studies reported on the well-being of employees in different sectors, within the healthcare system studies focused primarily on patients and less on those working there. The well-being and burnout of healthcare workers were analysed by Hall et al. (2016) in the context of patient safety in a systematic review. In Hungary, Deutsch et al. (2015) examined workplace factors which determine well-being among healthcare professionals, focusing on job satisfaction, work-life balance, self-efficacy and work-related stress.

The fundamental aim of our research was to examine the well-being of healthcare workers employed in county (state) hospitals, including nurses, and the factors influencing it. To achieve this, in addition to capturing certain dimensions of mental health (overall well-being, life satisfaction, burnout) we also explored the workplace climate. In our study we were seeking answers to the following questions:

1. What characteristics describe the well-being at work of nurses involved in the study? In what work environment do they do their daily activities?

2. To what extent is burnout typical among them?

3. In which factors does burnout differentiate regarding nurses?

\section{Material and methods}

Our cross-sectional, quantitative research was carried out using targeted non-random sampling between December 2019 and March 2020 in the county state hospitals of two cities in Southwest Hungary. Paper-based questionnaires were sent to all professionals in the participating hospitals who are directly involved in patient care or working in the field of diagnostics. Participation in the research was voluntary, and respondents' anonymity was assured. A total of 1,048 people completed the questionnaire. In the present study we only analyse the responses of those working in the nursing position $(n=581)$ and we do not wish to compare them with those working in other professional groups. Accordingly, our sample consists of a total of 581 nurses.

In addition to questions on sociodemographic (sex, age, highest level completed education) and workplace characteristics (number of years spent in healthcare, nature of professional qualification, work schedule), the measurement tool included validated questionnaires applied to explore mental health (Maslach Burnout Inventory, Diener Satisfaction with Life Scale, abbreviated Beck Depression Scale), as well as questions regarding the workplace climate.

Burnout was examined using the Hungarian version of the internationally validated and reliable Maslach Burnout Inventory - MBI, used in research of the service sector, which measures the three dimensions of burnout through 22 statements applying a seven-point Likert scale (Ádám et al., 2006; Maslach, 2003; Maslach and Jackson, 1981; Maslach et al., 1996).

To measure overall life satisfaction, we used the Hungarian version of Diener Satisfaction with Life Scale, which provides information about the respondent using a seven-point Likert scale with five statements (Martos et al., 2014).

The presence of depressive symptoms was justified using the Hungarian version of the abbreviated Beck Depression Scale with 9 statements (Rózsa et al., 2001).

To explore the workplace climate, we formulated a total of twelve statements, of which the first eight are consistent with the climate dimensions defined by Halász (1980), originally developed to examine school atmosphere, based on Halpin and Croft (1963) and Tagiuri and Litwin (1968). Moreover, we added four extra statements to the measurement tool, which allowed the respondent to globally evaluate job satisfaction, and his/her appreciation of colleagues and society.

\section{Statistical analysis}

During the statistical analysis, descriptive statistics were used to characterise the sample, and mathematical statistical tests (two-sample $t$-test, ANOVA, Chi-square test, correlation analysis, Mann-Whitney and Kruskal-Wallis test) were used to examine the correlations between the variables. The internal reliability of the questionnaires used was checked with Cronbach's Alpha. The results were considered significant at $p<0.05$ in all cases.

\section{Characteristics of the sample}

The nursing profession is known to attract mainly women, so it is not surprising that women are clearly over-represented among the respondents (88.6\%). Their average age is 45.03 years $( \pm 9.09)$. As for their highest level of education, it can be stated that it is a rather heterogeneous group. Although most of them have secondary and tertiary qualifications, approximately $14.5 \%$ work in patient care with a bachelor's degree and $1.4 \%$ with a university degree. Only 45 people $(7.7 \%)$ have only vocational education, and according to the data they belong to the older generation. In terms of specialties, the picture is extremely diverse: from the various specifications of internal medicine and surgery, to the pediatric ward and the nursing ward, all specialties are represented. 


\section{Main characteristics of mental health}

During the exploration of mental health, we mainly focused on overall life satisfaction, burnout and the presence of depressive symptoms. In measuring overall life satisfaction, as a first step, we added up the scale values assigned to each statement in the Diener Satisfaction with Life Questionnaire and then we formed categories. Overall, it can be concluded that the majority of nurses included in the study (about 74.5\%) were more satisfied with their lives than not, and only $21.7 \%$ indicated a scale value expressing dissatisfaction. As only one respondent expressed an extreme degree of dissatisfaction with life, their response was not included in further analyses regarding the variable.

\section{Results and discussion}

The results on life satisfaction are somewhat contradicted by the fact that only $8.3 \%$ of the respondents have no depressive symptoms at all, while $61.6 \%$ reported mild, $23.4 \%$ moderate, and $6.7 \%$ reported severe depressive symptoms. The degree of overall life satisfaction, and the degree of depression or its absence cannot be clearly linked to the work environment, it is not only a work-related feature, as it is affected by several areas of life and individual life events. However, it is undoubtedly inseparable from workplace components.

The relationship between work-related factors and mental health, especially among healthcare workers, can be clearly captured in the dimension of burnout. Basically, burnout can be defined in three distinct dimensions, which are depersonalization, emotional exhaustion and the feeling of reduced personal accomplishment. Accordingly, during the data analysis, we formed depersonalization, emotional exhaustion and reduced personal accomplishment variables by adding up the scale values associated with each dimension, which were then analysed. In the analysis we found that the average scores achieved in the dimensions of depersonalization and emotional exhaustion are well above the normal MBI values. The value measured in the personal accomplishment dimension among the nurses involved in the study proved to be higher than MBI normal values, which means that nurses feel their efforts to be more successful, more positive at work (Table 1).

Table 1. Relation of the average MBI values of Hungarian nurses to the results of the Maslach Burnout Survey (includes physicians and nurses' burnout scores) (Maslach and Jackson, 1981)

\begin{tabular}{|c|c|c|c|c|c|}
\hline & & $N$ & $\begin{array}{l}\text { Depersonalization } \\
\text { mean } \pm \text { SD }\end{array}$ & $\begin{array}{c}\text { Emotional exhaustion } \\
\text { mean } \pm \mathrm{SD}\end{array}$ & $\begin{array}{c}\text { Personal accomplishment } \\
\text { mean } \pm \text { SD }\end{array}$ \\
\hline Nurses & HU & 581 & $11.85 \pm(6.03)$ & $33.29 \pm(9.71)$ & $41.0 \pm(8.59)$ \\
\hline MBI norms & USA & 11,067 & $8.7 \pm(5.9)$ & $22.0 \pm(10.8)$ & $34.6 \pm(7.1)$ \\
\hline
\end{tabular}

\section{Organizational characteristics}

To explore the organizational dimension, which largely determines well-being at work, we examined the major components of institutional climate.

The results show that in the opinion of the respondents, efficiency, professional work along uniform guidelines and democratic management can be considered as strengths out of the institutional climate dimensions. However, it is a problem that in an area where teamwork is a part of everyday life, respondents feel that intimate, peer-to-peer partnership is less realized (Table 2 ).

\section{Differentiating factors of well-being at work}

After exploring the characteristics of the dimensions related to well-being at work, we wanted to find out along what factors life satisfaction and burnout of the respondents differentiate and what correlation these show with the characteristics of the workplace. Once we were convinced that the reliability index of the measurement tools we used was fairly high based on the responses of the nurses involved in the study (Cronbach's Alpha showed a value above 0.70 in all cases), in the first step we compared the examined variables with the sociodemographic characteristics. Examining life satisfaction, both sex and highest level of education proved to be differentiating factors. Regarding sex, it can be concluded that overall life satisfaction is higher among men $\left(\chi^{2}=17.998\right.$; $\left.\mathrm{df}=5 ; p=0.003\right)$, and in terms of completed education, those with a college or university degree proved to be more satisfied $\left(\chi^{2}=35.972\right.$; $\mathrm{df}=15$; $p=0.002)$. This finding is somewhat contradicted by the fact that depression is more prevalent among men, so much so that among them, signs of moderate depression are present in $33.8 \%$ of the respondents and signs of severe depression

\section{Table 2. Organizational characteristics}

Mean

1. In our ward, workers perform their healing activity along uniform guidelines

2. In our institution, professionals/doctors of different generations can work together harmoniously

3. The employees of our institution take part in tasks beyond nursing and healing activities in a committed and innovative way

4. At the workplace, intimate, peer-to-peer partnerships dominate

5. Our institution has developed good professional cooperation with partner institutions and professionals (e.g.: GP surgery, GP and dental primary care, other hospitals in the region)

6. The information flow between the manager and the subordinate employees functions properly

7. Our ward functions efficiently under the management of my superior

8. The management style of my superior is democratic

9. In our institution, professionals/doctors with different qualifications can work together harmoniously

10. Overall, I am satisfied with my current workplace

11. I feel that my workplace activity is highly appreciated by my colleagues

12. I feel that my workplace activity is highly appreciated by our society 
in $21.5 \%$. The difference between men and women was significant in the case of depression $\left(\chi^{2}=34.101 ; \mathrm{df}=3 ; p<0.001\right)$. Education is strongly differentiating with regard to depression as well, with the highest proportion of those with moderate or severe depressive symptoms among respondents with vocational education. The difference between particular school levels proved to be significant $\left(\chi^{2}=64.017 ; \mathrm{df}=9 ; p<0.001\right)$.

Examining burnout, it can be stated that there is a significant difference in the depersonalization dimension of burnout between the two sexes $(t=2.672 ; p=0.009)$; we measured a higher level of burnout among men. This difference was not demonstrated in either the dimensions of emotional exhaus- tion or personal accomplishment. In examining the differentiating effect of education, there was a considerable difference in depersonalization $(F=4.312 ; p=0.005)$, emotional exhaustion $(F=4.34 ; p=0.005)$, and personal accomplishment $(F=3.49 ; p=0.016)$ along the highest level of completed education. Regarding depersonalization it should be highlighted that the greatest degree of burnout can be measured among those with a college or university degree, while those who have vocational education are more at risk of emotional exhaustion. On the other hand, the feeling of personal accomplishment is the most favourable among those with vocational education (Table 3).

Table 3. Differentiating factors of burnout

\begin{tabular}{|c|c|c|c|}
\hline & $\begin{array}{c}\text { Depersonalization } \\
\text { mean } \pm S D\end{array}$ & $\begin{array}{c}\text { Emotional exhaustion } \\
\text { mean } \pm \text { SD }\end{array}$ & $\begin{array}{c}\text { Personal accomplishment } \\
\text { mean } \pm \text { SD }\end{array}$ \\
\hline \multicolumn{4}{|l|}{$\operatorname{Sex}(N=581)$} \\
\hline Male & $13.90 \pm 6.63$ & $35.30 \pm 10.57$ & $39.84 \pm 8.98$ \\
\hline Female & $11.60 \pm 5.91$ & $33.03 \pm 9.57$ & $41.15 \pm 8.53$ \\
\hline \multicolumn{4}{|c|}{ Education, highest level completed $(N=581)$} \\
\hline Vocational school & $12.17 \pm 5.16$ & $38.00 \pm 8.24$ & $42.91 \pm 6.18$ \\
\hline Secondary school graduation & $12.30 \pm 5.98$ & $32.54 \pm 9.33$ & $41.80 \pm 8.33$ \\
\hline Post-secondary vocational training & $10.50 \pm 8.00$ & $33.60 \pm 11,64$ & $39.44 \pm 9.72$ \\
\hline $\mathrm{BSc} / \mathrm{MSc}$ & $12.86 \pm 8.28$ & $32.65 \pm 6.49$ & $40.57 \pm 7.71$ \\
\hline
\end{tabular}

In the first step, in the relation between burnout and years spent at work, we examined the correlation between the two variables, but no significant relationship was proved for either dimension. In the first approach, it basically means that years spent at work do not contribute to burnout. Continuing the analysis, years spent at work were divided into 5-year periods. Examining the 5-year intervals, a fluctuating trend was observed in all three dimensions of burnout, with higher levels of burnout detected in some periods and lower levels in others. In the dimensions of depersonalization $(F=3.816 ; p<0,001)$ and personal accomplishment $(F=3.908 ; p<0.001)$ significant differences were demonstrated between the 5 -year periods. Although no significant difference was found in the dimension of emotional exhaustion, the fluctuating trend can be observed here as well.

As the focus of our present study is well-being at work, in the following we seek the answer to the question of how the mental health dimensions discussed above relate to how an employee feels at work and how they perceive the social appreciation of their work. Of the statements related to organizational characteristics, presented in Table 2, we formed a variable from the first eleven statements - as they are all directly related to the workplace and the colleagues - by adding up the scores assigned to each statement and comparing them to the mental health indicators discussed above.

The response to Statement 12, which relates to appreciation by society, was analysed separately. Analysing the relationship between sociodemographic variables and workplace characteristics, we may have discovered the effect of education only, and only in terms of appreciation by society $(F=3.529$; $p=0.015$ ). In this respect, it can be concluded that those with tertiary vocational education (based on secondary school graduation) perceive most that society appreciates the activity they perform. Although both life satisfaction and the development of depressive symptoms are complex phenomena influenced by several factors, we included these variables in the analysis. We did so because we believed that both the degree of overall life satisfaction and the presence and severity of depressive symptoms may be related to workplace factors.

While in the case of depressive symptoms we found a significant difference between the groups formed according to the severity of depressive symptoms only in the case of the variable 'appreciation by society' ( $F=3.418$; $p=0.017$ ), overall life satisfaction shows a significant correlation with both the organizational characteristics of the workplace $(F=2.875$; $p=0.009$ ), and the appreciation of the job position by society $(F=4.275 ; p<0.001)$.

In our research, we examined the well-being at work of nurses working in county state hospitals with the primary aim to explore the main characteristics of nurses' well-being at work and the factors influencing it - as well as the degree of burnout and depression occurring among them. We analysed the responses of 581 nurses to the questions covered by this study. Regarding overall satisfaction with life, it can be concluded that relatively few respondents $(21.7 \%)$ indicated a scale value expressing dissatisfaction. Examining life satisfaction, there was a significant difference between the examined groups both in terms of sex and the highest level of education. As for sex, there was a higher rate of overall satisfaction with life among men, just like among the general population (HCSO, 2018). The examination of the highest level of education revealed that those with a college or university degree were more satisfied, which can obviously be explained by the higher income level associated with the qualification and the resulting higher level of existential security.

According to 2020 estimations, nearly 264 million people suffer from depression worldwide (WHO, 2020), so the question of the extent to which nurses are affected was also emphasised in our research. Examining depression, it can be stated that the proportion of respondents who suffer from depressive symptoms is extremely high. About $6.7 \%$ reported severe depressive symptoms, while the same figure was $4.3 \%$ among the total female population and $2.6 \%$ among men (based on data from the 2016 population health survey). With regard 
to education, our results are in line with the findings of the population health survey, according to which the tendency to depression is higher than the average among those with low education (HCSO, 2018). A study with the same measurement tool in the same period but with a different professional group showed similar results (Fináncz et al., 2020).

During the analysis of statements referring to burnout, it was concluded that the degree of burnout appearing in the dimensions of depersonalization and emotional exhaustion far exceeds that of both physicians and nurses in the USA (Maslach and Jackson, 1981) and of Brazilian nurses (das Merces, 2020), which draws attention to the presence of the problem. It is also worth emphasizing that the values measured in Hungary, whether measured among radiographers or nurses, are very close to each other (Sipos et al., 2020). Higher scale values in the dimension of personal accomplishment indicate that respondents perceive the usefulness and effectiveness of their work in their daily activities (Table 4).

Table 4. Relation of the average MBI values of Hungarian nurses and radiographers and Brazilian nurses to the results of the Maslach Burnout Survey (includes physician and nurse burnout scores)

\begin{tabular}{lccccc} 
& & $N$ & $\begin{array}{c}\text { Depersonalization } \\
\text { mean } \pm \text { SD }\end{array}$ & $\begin{array}{c}\text { Emotional exhaustion } \\
\text { mean } \pm \text { SD }\end{array}$ & $\begin{array}{c}\text { Personal accomplishment } \\
\text { mean } \pm \text { SD }\end{array}$ \\
\hline Nurses & HU & 581 & $11.85 \pm(6.03)$ & $33.29 \pm(9.71)$ & $41.0 \pm(8.59)$ \\
Radiographers & HU & 404 & $12.8 \pm(6.6)$ & $34.3 \pm(12.9)$ & $41.0 \pm(8.7)$ \\
Brazilian nurses & Brazil & 1125 & $9.6 \pm(3.99)$ & $22.4 \pm 6.68$ & $30.4 \pm(6.27)$ \\
MBI norms & USA & 11,067 & $8.7 \pm(5.9)$ & $22.0 \pm(10.8)$ & $34.6 \pm(7.1)$ \\
\hline
\end{tabular}

In all three dimensions, the highest level of education proved to be a differentiating factor in the study of burnout as well. With regard to depersonalization, the greatest degree of burnout can be measured among those with a college or university degree, which may be related to the fact that they tend to work as senior nurses, who, due to their job position, work primarily not with patients but with doctors and other professionals; so during their work, responsibility and administrative burdens are more prevalent. Using this logic, we can explain the increased emotional exhaustion of those with vocational education, which can be attributed to the fact that they mainly perform their nursing activity at the sickbed. Continuous contact with patients and experiencing shocking situations exhausts professionals in the long run, especially those with high empathic skills. At the same time, it can be observed that the feeling of personal accomplishment is also the most favourable among respondents with vocational education. It is understandable in the sense that they can continuously fulfil their professional and personal competencies by satisfying the patients' needs and by daily nursing activities.

Examination of the connection between years spent at work and burnout did not show a linear relationship. However, dividing years spent at work into 5-year periods resulted in a completely different picture. In the dimensions of depersonalization and personal accomplishment there was a significant difference between the levels of burnout over the five-year periods, which suggests that during the years spent at work workload does not affect the individual to the same extent, or that the individual responds differently to challenges. It is particularly interesting to observe the dimension of personal accomplishment, where it can be seen that the initial high values, which reveal a kind of confidence, decrease after the first five-year period. This tendency may indicate that those leaving training are rather confident in their knowledge, but then their self-confidence declines as a result of self-reflection, which develops due to the failures and difficulties they experience. However, we must not ignore the fact that at the time of completing the questionnaire, a nurse in the first five-year period belongs to a generation which is basically characterized by a higher level of self-confidence and self-assertion. A similar tendency was observed among radiographers by Sipos et al. (2019) and also by Royer and Moreau (2015), who carried out their studies in a completely different professional group - among early childhood educators. The described phenomenon may be related to the so-called Dunning-Kruger effect, which states that entrants tend to overestimate their abilities and at the same time are unable to recognize their own limitations (Kruger and Dunning, 1999). Based on all this, we can state that the correlation between years spent at work and burnout can be justified, but the relationship is not linear.

To examine the organizational dimension that largely determines well-being at work, we applied a 12-statement measurement tool. Being healthcare institutions, it is not at all surprising that among the organizational characteristics, their strengths are efficiency and professional work along uniform guidelines. During patient care there is no room for individual thoughts or views, the decision on the treatment and therapy of the patients is made according to valid professional protocols, which are always based on evidence, so their effectiveness cannot be questioned. Of the statements, the one "I feel that my workplace activity is highly appreciated by our society" should be highlighted, in whose case the average score of the scale values (2.57) on average is 0.92 points lower than the average of the scale values assigned to the other statements. In Hungary, this tendency can also be observed among those working in early childhood education (Fináncz et al., 2020). This should be emphasised from the aspect that social appreciation can fundamentally determine the professional identity of a profession's members - in this case nurses.

Based on our findings, it can also be concluded that although several factors contribute to life satisfaction, the organizational characteristics of the workplace and the social appreciation of work-related activity considerably influence it.

In the correlation between well-being at work and mental health, the most important strategies are those related to social interaction inside and outside the organization, which suggests that strengthening rich social relationships both inside and outside the work environment contributes to employees' well-being (Menéndez-Espina et al., 2019).

\section{Conclusions}

In the present study, we examined the well-being of nurses working in county hospitals in Hungary. The findings draw attention to depression and burnout affecting them, and which 
show a correlation with workplace characteristics. The burnout rates of radiographers and nurses in Hungary can be considered unfavourable in relation to international comparison, therefore it is required to extend the study to other groups of health care workers.

It has to be mentioned that data collection was carried out in the pre-pandemic period and it is likely that a repeated data collection in the present situation would show completely different results. Because of all this, it is of special importance to promote well-being at work in job positions where burnout is an increased risk for employees exposed to constant mental strain.

\section{Conflict of interests}

The authors have no conflict of interests to declare.

\section{Limitations}

In the research, the questionnaires providing the basis of the analysis were distributed in two county hospitals in Western Hungary among professionals involved in patient care and diagnostics. The response rate was $69 \%$, so the answers to the questions do not reflect the characteristics of the whole population, and accordingly, our findings are of limited validity.

\section{Ethics}

Participation was anonymous and voluntary in the research, which has an ETT-REKEB (Regional Committee of Science and Research Ethics) ethical licence with the identifier 'Scientific work 25/2019'.

\section{Profesní duševní pohoda zdravotních sester v nemocnicích na jihozápadě Mad'arska}

\section{Souhrn}

Cíl: Účelem výzkumu bylo prozkoumat profesní duševní pohodu zdravotních sester v práci a její diferenciační faktory. Metody: Nástrojem prưřezového, kvantitativního a popisného výzkumu byl dotazník, který zahrnoval otázky týkající se sociodemografických charakteristik, spolu s validovanými dotazníky široce používanými v mezinárodní výzkumné literatuře [Maslach Burnout Inventory (dále jen MBI), Beck Depression, Diener Quality of Life], a otázky zaměřené na zkoumání situace na pracovišti. Respondenti byli cíleně vybráni a do analýzy byly zahrnuty odpovědi 581 zdravotních sester.

Výsledky: Při zkoumání syndromu vyhoření bylo zjištěno, že sestry zapojené do průzkumu vykazují nepříznivé výsledky v oblastech depersonalizace a emočního vyčerpání ve srovnání s normálními hodnotami MBI. Na druhé straně se průměrná hodnota vnímání osobního úspěchu mezi nimi ukázala být vyšší, což znamená, že respondenti cítí, že jejich snaha přnináší větší úspěch a pozitivitu na pracovišti. Celkovou spokojenost se životem významně ovlivňují organizační charakteristiky pracoviště $(F=2,875$; $p=0,009)$ a pozitivní vnímání práce zdravotních sester společností $(F=4,275 ; p<0,001)$.

Závěr: Podpora duševní pohody na pracovišti má zásadní význam pro zdravotnické pracovníky (kteří jsou stále více vystaveni stresu a syndromu vyhoření), zejména pak pro zdravotní sestry, které pracují v ústavní péči.

Klíčová slova: atmosféra na pracovišti; profesní duševní pohoda; syndrom vyhoření; zdravotní sestry

\section{References}

1. Ádám S, Győrffy Z, Csoboth C (2006). Kiégés (burnout) szindróma az orvosi hivatásban [Burnout syndrome in the medical profession]. Hippocrates 8(2): 113-117.

2. Aelterman A, Engels N, Petegem KV, Verhaeghe JP (2007). The wellbeing of teachers in Flanders: The importance of a supportive school culture. Educational Studies 33(3): 285-297. DOI: $10.1080 / 03055690701423085$.

3. Briones E, Tabernerro C, Arenas A (2010). Job satisfaction of secondary school teachers: effect of demographic and psycho-social factors. Revista de psicologia del trabajoy de las organizaciones 26(2): 115-122. DOI: 10.5093/tr2010v26n2a3.

4. das Merces MC, Coelho JMF, Lua I, de Souza e Silva D, Gomes AMT, Erdmann AL, et al. (2020). Prevalence and Factors Associated with Burnout Syndrome among Primary Health Care Nursing Professionals: A Cross-Sectional Study. Int J Environ Res Public Health 17(2): 474-485. DOI: 10.3390/ ijerph17020474.

5. Deutsch SZ, Fejes E, Kun Á, Medvés D (2015). A Jóllétet Meghatározó Tényezők Vizsgálata Egészségügyi Szakdolgozók Körében [Determinants Of Well-Being Among Health Care Professionals]. Alkalmazott pszichológia 15(2): 49-71. DOI: 10.17627/ALKPSZICH.2015.2.49.

6. Diener E, Emmons RA, Larsen RJ, Griffin S (1985). The Satisfaction with Life Scale. J Pers Assess 49(1): 71-75. DOI: 10.1207/s15327752jpa4901_13.

7. Diener E, Suh M, Lucas R, Smith HL (1999). Subjective well-being: three decades of progress. Psych Bulletin 125(2): 276-302. DOI: 10.1037/0033-2909.125.2.276.
8. Fekete S (1991). Segítő foglalkozások kockázatai Helfer szindróma és burnout jelenség [The Risks of Helping Professions. Helfer Syndrome and Burnout]. Psychiatria Hungarica 6(4): 17-27.

9. Fináncz J, Nyitrai Á, Podráczky J, Csima M (2020). Connections between Professional Well-Being and Mental Health of Early Childhood Educators. Int J Instr 13(4): 731-746. DOI: 10.29333/iji.2020.13445a.

10. Halász G (1980). Az iskolai szervezet elemzése [Analysis of School Organization]. Budapest: MTA Pedagógiai Kutatócsoport.

11. Hall LH, Johnson J, Watt I, Tsipa A, O'Connor DB (2016). Healthcare Staff Wellbeing, Burnout, and Patient Safety: A Systematic Review. PLoS One 11(7): e0159015. DOI: 10.1371/journal.pone.0159015.

12. Halpin AW, Croft DB (1963). The Organisational Climate of Schools. Chicago: Midwest Administration Centre, University of Chicago.

13. HCSO (2018). A 2014-ben végrehajtott Európai lakossági egészségfelmérés eredményei. Összefoglaló adatok [Results of the European Public Health Survey conducted in 2014. Summary data]. [online] [cit. 2020-04-07]. Available from: http://www.ksh.hu/docs/hun/xftp/idoszaki/elef/elef2014_ osszefoglalo.pdf

14. Hegedűs R (2001). Szubjektív társadalmi indikátorok - szelektív áttekintés a téma irodalmából [Subjective social indicators a selective review of the topic literature]. Szociológiai Szemle 2: 58-72.

15. Kopp M, Kovács ME (2006). Az életminőség kutatás jelentősége a népesség jóllétének vizsgálata céljából: interdiszciplináris modell [The importance of quality of life research to examine the well-being of the population: an interdisciplinary model]. 
In: Kopp M, Kovács ME (Ed.). A magyar népesség életminősége az ezredfordulón [The Hungarian Population's Quality of Life at the Millennium]. Semmelweis, Budapest, pp. 2-9.

16. Kruger J, Dunning D (1999). Unskilled and Unaware of It: How Difficulties in Recognizing One's Own Incompetence Lead to Inflated Self-Assessments. J Pers Soc Psychol 77(6): 1121-1134. DOI: 10.1037//0022-3514.77.6.1121.

17. Martos T, Sallay V, Désfalvi J, Szabó T, Ittzés A (2014). Az Élettel való Elégedettség Skála magyar változatának (SWLS-H) pszichometriai jellemzői [Psychometric characteristics of the Hungarian version of the Satisfaction with Life Scale (SWLS-H)]. Mentálhigiéné és Pszichoszomatika 15(3): 289-303. DOI: 10.1556/Mental.15.2014.3.9.

18. Maslach C (2003). Job Burnout: New Directions in Research and Intervention. Current Directions in Psychological Science 12(5): 189-192. DOI: 10.1111/1467-8721.01258.

19. Maslach C, Jackson SE (1981). The measurement of experienced burnout. J Org Behav 2(2): 99-113. DOI: 10.1002/ job.4030020205.

20. Maslach C, Jackson SE, Leiter M (1996). Maslach Burnout Inventory Manual. Consulting Psychologist Press, Palo Alto, CA.

21. Menéndez-Espina S, Llosa JA, Agulló-Tomás E, RodríguezSuárez J, Sáiz-Villar R, Lahseras-Díez HF (2019). Job Insecurity and Mental Health: The Moderating Role of Coping Strategies From a Gender Perspective. Front Psychol 10: 286. DOI: $10.3389 /$ fpsyg.2019.00286.

22. Royer N, Moreau C (2015). A survey of Canadian early childhood educators' psychological wellbeing at work. Early Child Educ J 44(2): 135-146. DOI: 10.1007/s10643-0150696-3.

23. Rózsa S, Szádóczky E, Füredi J (2001). A Beck Depresszió Kérdőív rövidített változatának jellemzői hazai mintán [Characteristics of the abbreviated version of the Beck Depression Questionnaire in a domestic sample]. Psychiatria Hungarica 16(4): 384-402.

24. Sipos D, Freihat O, Pandur AA, Tollár J, Kedves A, Repa I, et al. (2020). Possible predictors of burnout among radiographers in Hungary: demographic and work related characteristics. Kontakt 22(4): 228-234. DOI: 10.32725/kont.2020.038.
25. Sipos D, Vandulek C, Petone CSM, Kedves A, Pandur AA, Boncz I, et al. (2017). The attrition and migration behaviour among Hungarian radiographers. Glob J Health Sci 10(1): 1-10. DOI: 10.5539/gjhs.v10n1p1.

26. Sipos D, Varga V, Pandur AA, Kedves A, Csima MP, Cseh S, et al. (2019). Radiológiai osztályon dolgozó szakdolgozók kiégési szintje Magyarországon [Burnout level among radiology department workers in Hungary]. Orvosi Hetilap 160(27): 1047-1056. DOI: 10.1556/650.2019.31442.

27. Szabó L (2003). A boldogság relatív - Fogyatékosság és szubjektív életminőség [Happiness is relative - Disability and subjective quality of life]. Szociológiai Szemle 13(3): 86-105.

28. Szántó Z, Susánszky É, Berényi Z, Sipos F, Murányi I (2016). A jól-lét fogalmának értelmezése az európai szakirodalomban (2009-2014) [Interpretation of the concept of well-being in the European literature (2009-2014)]. Metszetek 5(1): 16-47. DOI: $10.18392 / \mathrm{metsz} / 2016 /$.

29. Tagiuri R, Litwin G (1968). Organizational climate: Explorations of a concept. Boston: Harvard Business School.

30. Tomo A, de Simone S (2017). Exploring Factors that Affect the Well-Being of Healthcare Workers. Int J Bus Manag 12(6): 49-61. DOI: 10.5539/ijbm.v12n6p49.

31. van Horn JE, Taris TW, Schaufeli WB, Schreurs PG (2004). The structure of occupational well-being: A study among Dutch teachers. J Occup Organ Psychol 77: 365-375. DOI: $10.1348 / 0963179041752718$

32. Veenhoven R (2007). Quality of life research. In: Bryant CD, Peck DL. 21st Century Sociology, A Reference Handbook. Sage, Thousand Oaks, California, USA. 2, pp. 54-62.

33. Warr P (1994). A conceptual framework for the study of work and mental health. Work \& Stress 8(2): 84-97. DOI: $10.1080 / 02678379408259982$.

34. WHO - World Health Organization (2020). Depression. [online] [cit. 2020-08-09]. Available from: www.who.int/news-room/ fact-sheets/detail/depression

35. Yildirim K (2014). Main factors of teachers' professional well-being. Educational Research and Reviews 9(6): 153-163. DOI: 10.5897/ERR2013.1691. 